\title{
The Framing of Contemporary Christian Apostasy on the World Wide Web
}

\author{
Douglas J. Swanson \\ Department of Communication Studies \\ University of Wisconsin-La Crosse
}

\begin{abstract}
This article is a preliminary effort to make conclusions about how apostate religious organizations use the World Wide Web for information dissemination, evangelization, and proselytization. Ten Christian apostate group Web sites were subjected to a frame analysis that focused on perceived intent, protest, expression, justification, response options, and rewards offered. The analysis revealed most sites were perceived to use an information dissemination rather than evangelization or proselytization frame. Response options and rewards were mostly consistent with the expression of, and justification for, apostasy. However, only 2 of the sites framed apostasy at its highest level. Most did not address the critical issue of worship service attendance, and most may put followers in a potentially awkward and ethically inconsistent position by not asking followers to disaffiliate from the opposed religious group while actively seeking followers' disengagement from that group's theology.
\end{abstract}

The World Wide Web is a fairly new technological advancement, so it has only been within the past few years that much scholarly research has focused on its use. There are still many gaps in the literature. In particular, there has not been a great deal of attention paid to the subject of how religious organizations use the Web for information dissemination, evangelization, and proselytization-three primary strategic goals for a religious entity.

There continues to be tremendous growth among consumers who use the Web as an information resource. Between 2000 and 2002, CommerceNet estimated a $40 \%$ increase in users worldwide-with 349 million people now using the Web and 
one third of those users in the United States (CommerceNet WorldWide Internet Population, 2002). Although it is difficult to quantitatively estimate growth in online content, researcher R. H. Zakon estimated that somewhere between $35 \mathrm{mil}$ lion and 40 million Web sites existed online in March 2002. This represents a 100\% growth since March 2000 (Zakon, 2002). Clearly we live in a world where there is increasing use of electronic information sources. At the same time, we live in a world where people are increasingly skeptical of the actions of organized religion (Barr, 1988; Barron, 1993). Thus, it is important to have a greater understanding of religious content available on the Web, along with more complete knowledge of how the public evaluates electronically disseminated messages.

This article evaluates the use of World Wide Web sites by a small number of Christian apostate groups based in the United States. Apostate groups were chosen because it could be argued that they would be among those religious entities with the most to gain by using a still-developing medium to reach the public.

Web site content put forward by these apostate groups was studied through frame analysis, a method where the investigator proceeds to "select some aspects of a perceived reality and make them more salient in a communicative text" (Entman, 1983, p. 52) to define and interpret communication content. The frame analysis in this article focused on the extent to which apostate Web sites identified, expressed, and justified their apostate intent; asked users to respond; and offered or promised rewards for user response. Results of the analysis were examined to reach conclusions about the effectiveness of strategies employed by these specific apostate groups and to make suggestions about more effective use of the controlled medium of the World Wide Web.

\section{THE RELIGIOUS EXPERIENCE}

The need to believe in an ethereal being or God is "a part of our nature, built into our neuronal mainframe" (Shermer, 2000, p. 47) as human beings. Human beings want to believe in a greater power and, at the same time, want to share this religious experience. This sharing allows humans to integrate spirituality into their personal and professional lives (Schneiders, 1989).

For most religious people, this shared experience takes place within the organizational structure commonly referred to as the church. Within the church, followers develop their spiritual beliefs in accordance with the theology of the host denomination (Neck \& Millman, 1994). Followers align their values with the organization to reflect "emotional investment" (Dehler \& Welsh, 1994, p. 22) in its structure. Followers submit to and participate in "relationship-based organizing" (Sass, 2000, p. 201), which connects participants, their values, and activities in socially meaningful and supportive ways. The result is a religious organization that can interpret the world and its relationships for followers and the general public (Appelrouth, 1999). 
At the same time, the organization creates a religious identity for itself. In the United States, Caplovitz observes that this identity rests on two foundations- "a commitment to religious beliefs and practices and a feeling of kinship with a social group united by a common religious tie" (Caplovitz, 1977, p. 181).

In recent years, Christian churches have faced a number of troubling issues. Beginning in the early 1980s, a progression of moral scandals caused many Americans to lose faith in religious denominations and those who led them (Gamson, 2001; Lord, 1987). These scandals involved financial misappropriation (Barr, 1988; Fraser, 1999), sexual misconduct by leadership (Gamson, 2001), the public expression of impolite comment by leadership ("Falwell apologizes to gays...," 2001), and accusations of intellectual dishonesty ("Swaggart accused of plagiarism," 2001). A world-wide scandal even left the once-sacrosanct Catholic Church to be widely perceived as manipulative and corrupt to its very core (Collins, 2002).

Public support for religious denominations has been shown to drop dramatically in the wake of scandal (Fan, Wyatt, \& Keltner, 2001). It has also been suggested that, in recent years, at least partially in response to scandal, an increasingly cynical public has been shying away from some denominations and churches based on the perception that they "cause more problems than they solve" (Barron, 1993, p. A1). It could be argued that the recent social and cultural climate is quite favorable to the development of apostate religious organizations that help people meet spiritual needs that are not being addressed by mainstream denominations, churches, and theologies.

\section{THE EXPERIENCE OF APOSTASY}

An apostate is a person who at one time identified with a particular religious denomination, but for one or more reasons subsequently severed the relationship. The apostasy process begins with "individuals experiencing doubts about the viability of religious life and their own commitment to that life" (Bromley, 1988, p. 15). The highest level of apostasy is that of personal "disengagement" (Bromley, $1988, \mathrm{p} .16)$ from the religious denomination. Apostasy involves more than church membership. "Apostasy implies a rejection, not just of religious identity, but, in part, of the dominant culture's values" (Hadaway \& Roof, 1988, p. 30).

It is not unusual for those who become apostates to experience great personal and emotional suffering. They are often rejected by family members and friends (Lobdell, 2001). In some cultures, apostates are accused of having psychological problems (Witham, 1998), threatened with death or killed.

Apostates often break from the established group during times of rapid social change that are already difficult for people to deal with (Wright, 1988). Apostates may have a higher level of social mobility in society, making them already subject to "transitory and impermanent attachments and affiliations" (Wright, 1988, p. 164). 
The media add to the difficulty of the situation by commonly categorizing apostate groups among sects and cults in a way that they are perceived as deviant (Witham, 1998). Witham said this editorial treatment results from news media logic that seeks to draw attention to unusual behavior that results in social conflict. It also results from input by family and friends of religious group members who pressure media to expose alleged wrongdoing by dissenters. The process is exacerbated by mainstream religious groups that "add the aura of established religious authority to criticism of small groups" (Witham, 1998, p. 3).

\section{THE ONLINE EXPERIENCE}

Technology "is the distinct cultural activity in which human beings form and transform natural reality for practical ends" (Christians, 2002, p. 38). The establishment of a World Wide Web site is a technological endeavor that allows people to indirectly define themselves and their activities (Papacharissi, 2002). This is as true for individuals as it is for organizations.

The Web site hosted on behalf of an apostate group is a distinct cultural "reality" with the potential to accomplish three key objectives. The first is information dissemination. A Web site can create an inward sense of community, as those who have disaffiliated share their stories about the religious denomination they left behind. At the same time, the Web site can allow these stories to be shared with the general public, to provide information about the apostate movement. The Web site also allows an apostate group to evangelize, or communicate persuasively with followers and the general public about the group's theology and organizational structure. Finally, the Web site allows for proselytization, through which the organization identifies and recruits new followers.

The Web site allows an apostate movement to be legitimized in a number of ways. It can help build a dialogue with the public, solicit volunteers, encourage study of the issues, and even raise money and sell merchandise to further group objectives or work against the objectives of the opposed religious organization.

\section{RESEARCH DESIGN}

This research was designed to avoid three criticisms directed toward other recent research in mass communication. The first of these criticisms is that mass communication research often is lacking in theoretical grounding and hypothesis development. A study of almost 900 mass communication research articles published during the 1980 s and 1990 s found that only one third made a specific reference to a guiding theory (Kamhawi \& Weaver, 2003). A similar finding was reported by Riffe and Freitag (1997) in a study of articles published in 10 major communications journals over a 25-year period. Riffe and Freitag also reported that about half of 
mass communication research employing content analysis failed to have a developed hypothesis or research question. In an effort to avoid these problems, the study reported here uses a single guiding theory that has been used extensively in past mass communication research and has been seen as an especially valuable tool to make sense of communication in public relations (Knight, 1999). The research employs content analysis methods, but also has three specific research questions that tie directly to the theoretical model.

In addition to the structural development problems noted in past mass communication research, it has also been noted that the vast majority of this research published in major journals has been quantitative in nature (Perloff, 1976; Potter, Cooper, \& Dupagne, 1993; Kamhawi \& Weaver, 2003). This suggests a limited opportunity for scholars to discuss findings that cannot be expressed in numeric terms. As a result, at least one researcher has called for scholars to do a better job of combining quantitative with qualitative methods (Weaver, 1993). The study reported here attempts to be as descriptive as possible by using methods that result in development of both quantitative and qualitative findings.

A final criticism of other studies in mass communication has to do with the fact that existing work is overwhelmingly focused on traditional media-chiefly print journalism and television broadcasting. Despite tremendous popular interest in the Internet, Kamhawi and Weaver (2003) found that less than 7\% of published research between 1980 and 1999 addressed the Internet. More than $70 \%$ of the work in this time period addressed traditional print and/or broadcast media (Kamhawi \& Weaver, 2003). The study reported here, although preliminary in nature, addresses an aspect of Internet communication not previously dealt with in the literature and does so using commonly accepted research theory, research design, and methodology.

The study reported here focuses on how apostate World Wide Web sites frame relevant issues. A frame serves as a means for organizing information that allows members of publics to adopt particular beliefs (Brewer, 2002). A frame can organize key words, phrases, or themes (Scherer, 2002); audio/visual messages (Hung, 2001); graphic images such as photos or cartoons (Ragan, 1979); or sources from which information originates or to whom it is attributed (Entman, 1983). Frames can be used to describe or characterize the communicative relationships that take place as a result of gender (Devitt, 2002) or ethnicity (Moody-Hall, 2002) or any of numerous other explicit or implicit variables (Hung, 2001) that result in-and result from-communication.

It has been common practice for media researchers to identify and analyze frames that are established through media content. There is extensive literature support for use of this theoretical perspective-particularly in regard to the news media and public relations industries and their communicative output (Bensimon, 1987; Brewer, 2002; Knight, 1999; Moody-Hall, 2002; Scheufele, 1999).

Research conducted within this perspective helps scholars better understand the choices made by media managers. It is these choices that "lead to emphasis upon certain features of a news story and, in turn, significantly structure citizens' 
responses to public events and issues" (Shah, Watts, Domke, \& Fan, 2002, p. 370). In particular, framing allows media constructions through which the public can understand politics as well as understand the discourse through which politics is explained (Shah et al., 2002).

Framing allows those who would hope to control politically oriented dialogue to define their role as a leader (Bensimon, 1987). Significant risks are involved, however, because the individual can easily be perceived as "intrusive, disruptive, contentious, or evasive" (Simons, Morreale, \& Gronbeck, 2001, p. 128) if the communication is not in synch with the perceptions of publics being addressed. In some situations, the communicator who tries to take political advantage through interpretation can actually cause the public to be more intense in its support for a noninterpreted, or unreframed, issue (Shah et al., 2002).

In any analysis of the framing of an issue, it is important to examine the frame itself and the way the frame is operationalized (Scheufele, 1999). The use of different types of frames can be examined in retrospect (Bensimon, 1987) and made subject to ethical analysis to assess issues of intent, consistency, accuracy, and validity (Cutbirth, Shapiro \& Williams, 1983). Appropriate use of framing allows the communicators to isolate issues that are salient for public discussion from those that are not (Tankard, 1997) and to engage in "selecting and emphasizing certain aspects of experience or ideas over others" (Andsager \& Smiley, 1997, p. 2).

Although much of the frame analysis research focuses on frame choice and construction by members of the media, it has also been argued that media consumers look for frames as they seek out order or "organization of experience" that framed messages provide (Jah-Nambiar, 2002). Individuals can be persuaded to reproduce beliefs about social, cultural, and economic power as a result of media discourse that frames issues in terms that people can logically and emotionally identify with (Tucker, 1998).

Taken as a whole, existing research clearly demonstrates that frame analysis is an appropriate means for assessing content of online messages. To a certain extent, the results of such analysis can also reach conclusions about the likely communicative intent of Web site creators (Lindlof \& Taylor, 2002).

In the case of this particular research, three research questions (RQs) were posed in regard to Web sites hosted on behalf of contemporary Christian apostate groups in the United States:

RQ 1: To what extent do apostate Web sites identify, express, and justify apostate intent?

RQ 2: What response options and rewards are offered for visitors to apostate Web sites?

RQ 3: What similarities and differences can be observed among apostate group Web sites that frame similar denominational and theological protests? 


\section{METHODOLOGY}

This research was conducted with the assistance of 50 upper-division Communication Studies students who were enrolled in "Public Relations Tools \& Strategies," a course offered in the fall of 2002 at a large regional state university in the upper Midwest. The use of undergraduate student researchers allowed the students to gain hands-on experience in research methods and also lessened the opportunity for individual researcher bias. All work was completed between September 18 and November 1, 2002.

On the first day of the project, the concept of apostasy was defined by the instructor and explained with general examples. Students were then asked to conduct a World Wide Web search for articles that offered narratives of the apostate experience. Each student had a computer terminal with unrestricted Internet access. Students were allowed to determine search strategies for themselves and evaluate search outcomes without instructor input. The initial search results were reviewed by the instructor to assure students understood the concept of apostasy. Search results were discarded.

On a subsequent class meeting, students were asked to search for and identify Web sites hosted by apostate groups. The 13 sites most commonly identified by students in this search were isolated for study. Three sites were later dropped because a further investigation by the instructor determined them to be thematically or operationally inconsistent with the research objective.

In a final session, students were presented with the list of $10 \mathrm{Web}$ sites to be analyzed. Students were given a list of content-related themes through which the frame analysis was to be conducted. Each student chose a Web site from the list, evaluated the site, and answered a series of questions about their perceptions of the site. All work was completed individually outside of class. No time limit was established for site visits. Findings were reported in writing. Each of the 10 sites was evaluated by at least 3 students.

After receiving students' written evaluations, the instructor visited each of the $10 \mathrm{Web}$ sites. The instructor reviewed the findings of the student visits, summarized qualitative and quantitative results, adjudicated any reported differences of opinion from student visits, made observations of his own, and drafted conclusions.

\section{RESULTS}

Ten Web sites representing Christian apostate organizations were analyzed. The site names, URLs, names of sponsoring apostate groups, and names of religious groups opposed are shown in Table 1.

The content-related frames developed by the researcher to serve as the basis for gathering data to address RQ 1 are shown in Table 2 . The content-related frames developed by the researcher to serve as the basis for gathering data to address RQ2 are shown in Table 3. Frame development was consistent with the standards established 
TABLE 1

Web Sites Evaluated

\begin{tabular}{|c|c|c|}
\hline Web Site Name ${ }^{a}$ & World Wide Web Site & Organization Opposed \\
\hline $\begin{array}{l}\text { Endtime (Christian Science } \\
\text { Endtime Center) }\end{array}$ & http://www.endtime.org & Church of Christ Scientist \\
\hline Emergence International & http://www.emergence-international.org & Church of Christ Scientist \\
\hline Christian Way & http://www.christianway.org/ & Church of Christ Scientist \\
\hline Mainstream Baptist Network & http://www.mainstreambaptistnetwork.org & Southern Baptist Convention \\
\hline Cooperative Baptist Fellowship & http://www.cbfonline.org/indext.cfm & Southern Baptist Convention \\
\hline $\begin{array}{l}\text { Rainbow Baptists (American } \\
\text { Baptists Concerned) }\end{array}$ & http://www.rainbowbaptists.org/ & Southern Baptist Convention \\
\hline $\begin{array}{l}\text { The Truth About Jehovah's } \\
\text { Witnesses (Timothy Campbell)* }\end{array}$ & http://www.mypage.uniserve.ca/ & $\begin{array}{l}\text { Jehovah's Witnesses } \\
\text { (Watchtower Bible and Tract } \\
\text { Society of Pennsylvania) }\end{array}$ \\
\hline $\begin{array}{l}\text { Beyond Jehovah's Witnesses } \\
\text { (Timothy Campbell) }\end{array}$ & http://www.members.aol.com/beyondjw/ & $\begin{array}{l}\text { Jehovah's Witnesses } \\
\text { (Watchtower Bible and Tract } \\
\text { Society of Pennsylvania) }\end{array}$ \\
\hline Reaching Catholics for Christ & http://www.reachingcatholics.org & Catholic Church \\
\hline $\begin{array}{l}\text { Affirmation: Gay \& Lesbian } \\
\text { Mormons }\end{array}$ & http://www.affirmation.org/ & $\begin{array}{l}\text { Church of Jesus Christ of } \\
\text { Latter-day Saints (Mormons) }\end{array}$ \\
\hline
\end{tabular}

aName is followed by name of sponsoring apostate group, if different.

*This website is currently not available.

by Scheufele (1999). The resulting data analysis was consistent with common expectations within this perspective (see Bensimon, 1987; Brewer; 2002; Cutbirth, Shapiro \& Williams, 1983; Knight, 1999; Swanson, in press; Tankard, 1997).

\section{RQ 1: To what extent do apostate Web sites identify, express, and justify apostate intent?}

Most of the apostate Web sites (7 out of 10) were determined to represent established organizations that were beyond the formative stage. Two sites were determined to represent individual activists, and 1 site represented what appeared to be a loosely associated group of people sharing a common set of beliefs.

All 10 sites were perceived to be framed primarily for dissemination of information. This was displayed through fairly extensive detail about apostate movements, participants, and participants' personal and organizational goals. Evaluators perceived 1 of the 10 sites was also highly oriented toward evangelization; 2 others were also highly oriented toward proselytization.

Nine sites were perceived to be strongly framing a protest of a religious denomination's theology or a specific tenet of that theology. Two of the 10 sites also were perceived to frame protest of a specific religious denomination in addition to protest of its theology. Three sites also appeared to focus protest on specific actions taken by the opposed religious denomination-in 1 case, for example, citing in- 
TABLE 2

Apostate Web Site Organizational Structure, Framing of Apostate Intent, Target of Protest, Expression of Apostasy, and Justification for Actions as

Perceived by Evaluators

Content-related frames/intent

END EMR CWY MBN CBF RBT TJW BJW RCC AFF

Organizational structure

Single individual

Group of individuals (loosely associated)

Organization currently forming

Established organization (not in formative stage)

Primary identification of apostate intent

Informational

Evangelistic/ministerial

Proselytization

Primary focus of protest

A specific religious denomination

A specific denomination's religious theology

Specific tenet(s) of a denomination's theology

Specific action(s) taken by a religious denomination

Primary expression of apostasy

Logically expressed (facts, figures, objective data, etc.)

Emotionally expressed (narratives, testimonies, photos, etc.)

Primary justification of apostasy

Divine command

Revealed truth

Prophetic command

Intellectual satisfaction

Spiritual or emotional satisfaction

Lifestyle improvement

Civil or human rights necessity

Political necessity

Economic necessity

To alleviate religious persecution

To avoid punishment

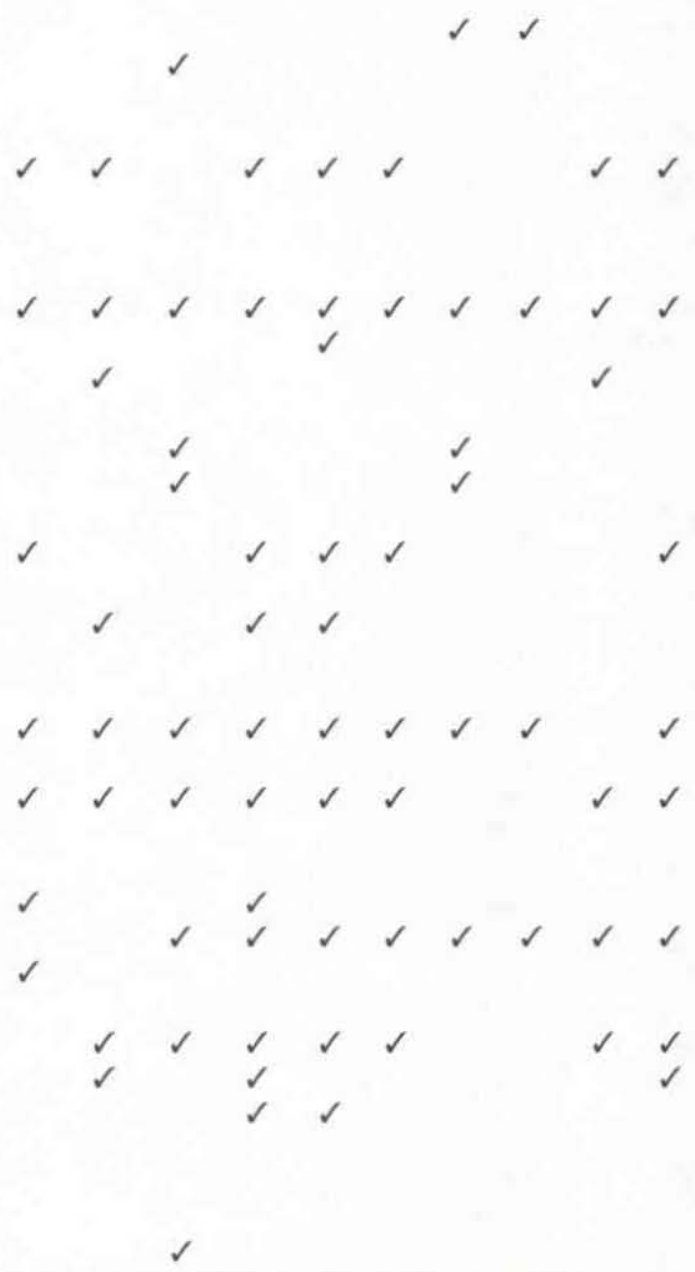

$\mathrm{END}=$ Endtime $; \mathrm{EMR}=$ Emergence International $; \mathrm{CWY}=$ Christan $\mathrm{Way} ; \mathrm{MBN}=$ Mainstream Baptist Network; $\mathrm{CBF}=$ Cooperative Baptist Fellowship; $\mathrm{RBT}=$ Rainbow Baptists; TJW $=$ The Truth About Jehovah's Witnesses; RCC $=$ Reaching Catholics for Christ; AFF $=$ Affirmation.

${ }^{\mathrm{a}} \mathrm{n}=10$. 
TABLE 3

Apostate Web Site Primary Desired Response(s) from Public(s), Reward(s)s Offered as Perceived by Evaluators

Content-related frames/
response \& reward
END

Primary Desired Response(s) from Public(s)

Share information with others

Be evangelized; change your beliefs

Become a proselyrizer; encourage others to join this movement

Attend a worship service of this movement

Read/study the scripture or related information

Volunteer to help the movement in a service capacity

Donate money

Engage in a dialogue/discussion with organizers

Make a purchase

Request further information about the movement

Primary Reward(s) Offered to

Public(s)

Rightness with God

Rightness with truth

Rightness with prophetic vision (of apostate prophet or founder)

Intellectual satisfaction

Spiritual or emotional satisfaction

Lifestyle enhancement

Civil or human rights, acceptance, or related satisfaction

Political rights, acceptance, or related satisfaction

Economic improvement

Freedom from religious persecution

Freedom from punishment (e.g., hell or damnation)

$\mathrm{END}=$ Endtime $; \mathrm{EMR}=$ Emergence International $\mathrm{CWY}=$ Christan Way; $\mathrm{MBN}=$ Mainstream Baptist Network; CBF = Cooperative Baptist Fellowship; RBT = Rainbow Baptists; TJW = The Truth About Jehovah's Witnesses; $\mathrm{RCC}=$ Reaching Carholics for Christ; $\mathrm{AFF}=$ Affirmation .

${ }^{a} \mathrm{n}=10$. 
stances in which the apostate believers had been "condemned and cut off from the mainstream" in the organization to which they formerly belonged.

Most sites ( 7 out of 10 ) were perceived to balance the framing of logically and emotionally based persuasive arguments. Two of the sites, both targeting Jehovah's Witnesses, were perceived to be structured mostly around logical arguments to support leaving the denomination. One site, Reaching Catholics for Christ, was perceived to be structured around emotional arguments for "biblical salvation [through] the body of Christ."

Most of the sites were perceived as framing apostasy as justified in search of revealed truth ( 8 out of 10 sites); as a necessary action to bring about spiritual or emotional satisfaction ( 7 out of 10 sites); or to bring about lifestyle improvement, support civil or human rights, or as politically necessary ( 8 out of 10 sites). Evaluators perceived only 2 of the sites to be framing apostasy as a response to a divine command; only 1 site seemed to frame apostasy as a means of avoiding punishment, hell, or damnation. None of the sites was perceived to frame apostasy primarily as a means of achieving intellectual satisfaction, as an economic necessity, or as a means of avoiding persecution from an opposed religious denomination.

\section{RQ 2: What response options and rewards are offered for visitors to apostate Web sites?}

Evaluators perceived that the majority of apostate Web sites framed opportunities for response as primarily reading/study of scripture and related information (8 out of 10), evangelization/change of beliefs ( 5 out of 10 ), engagement in a dialogue/discussion with organizers ( 4 out of 10 ), and requests for further information ( 4 out of 10). The issue of proselytization — seeking out others to convert to the cause - was strongly framed by only 3 sites. Only 2 sites explicitly framed attendance at a religious service as a response option.

Evaluators perceived that rewards offered for Web site visitors were fairly consistent with the way apostasy was framed as a justifiable action. Revealed truth and spiritual or emotional satisfaction were the predominant justifications for apostasy. Likewise, sites were perceived to frame key rewards for visitors as rightness with truth ( 7 out of 10) and spiritual or emotional satisfaction (6 out of 10$)$. The rewards of lifestyle improvement, civil or human rights, acceptance, or satisfaction, and political rights, acceptance, or related satisfaction were framed strongly by a total of 5 out 10 sites. Although several of the sites strongly emphasized the rightness of the apostate group founder or prophet, only 1 site strongly framed the personal reward that comes from alignment with this vision.

\section{RQ 3: What similarities and differences can be observed among apostate group Web sites that frame similar denominational and theological protests?}

Of the 10 apostate Web sites chosen for evaluation, 3 represent groups opposing the Church of Christ, Scientist-better known as the Christian Science Church. 
Christian Science is said to offer "a method of prayer that is simple, scientific and effective in bringing about healing and regeneration" (Beals, 2002). A Christian Scientist "draws upon the power of God to destroy the negative thoughts that cause all discord" (Beals, 2002). Founded in Boston, Massachusetts, in the late 1800 s, the church experienced its greatest growth in the post-World War 2 years. Since then, several well-publicized scandals have rocked the denomination, and today the church is recognized to be in decline due to membership attrition and members' inability to modernize doctrine, engage in debate, or actively publish literature not approved by the church (Swanson, 2001).

Because denominational changes are prohibited without the approval of founder Mary Baker Eddy — who died in 1910 - humorist Mark Twain suggested Christian Scientists had no more say in the management of their church than audience members would have in the management of a theater (Twain, 1907). Over the years, many Scientists also have taken this view.

The 3 apostate Web sites opposing Christian Science are Endtime, Emergence, and Christian Way. All share some similarities. Each is strongly focused on delivering information and makes effective use of articles and personal testimony to tell the story of its apostate movement and impact on adherents. Each uses logic and emotion to balance the arguments being made. Each is visually complex, is operationally sophisticated, and encourages interaction with users through "Question and Answer" pages and e-mail/discussion board links.

The sites differ most notably in their intent and expression of protest. Endtime is filled with praise for Mary Baker Eddy and her vision - but protests her church's theology, which it claims fails to "extend pure Christian Science" to the world. The Endtime site includes a large volume of reference materials and scripture readings in addition to articles and testimonials that it claims to be more theologically appropriate than those offered by Mrs. Eddy's church. The Emergence International site is sponsored by an organization established specifically to support gay, lesbian, bisexual, and transgendered (GLBT) Christian Scientists. Emergence, too, offers praise of Mrs. Eddy - but that praise is limited and couched amid the claim that "[s]ince the beginning of the Christian Science Movement, many GLBT members have felt condemned" by their church. Although both Endtime and Emergence criticize the Boston leadership, neither site encourages members of the Church of Christ, Scientist to abandon their church. The Christian Way site, on the other hand, is at the opposite end of the spectrum. Christian Way strongly encourages Christian Scientists to leave their church and its teachings to be free from "spiritual, emotional, and physical harm" as well as avoid eternal damnation. Christian Way has nothing good to say about Mrs. Eddy or her prophetic vision. As such, it demonstrates a clear proselytization intent and is the only site of the 3 to identify its followers as "former Christian Scientists." Overall, the Christian Way site is so evangelical in nature that the references to Christian Science could easily be removed and the site could carry forward solely the strength of its pledge of "sharing the gospel of Jesus Christ." 
Three of the Web sites chosen for evaluation in this study represent groups opposing the Southern Baptist Convention (SBC). Historically, Baptists held the position that each believer was capable of interpreting the scriptures individually and that each person was "directly accountable to God for his/her beliefs and actions" (Prescott, 2000). In recent years, the SBC has taken its Baptist Faith and Message (2000) from a loosely organized, nonbinding statement to a strongly worded creed that makes Baptists accountable to their churches and to each other for their beliefs and actions. As currently interpreted, the Baptist Faith and Message takes the position that the Bible is the literal word of God. This fundamentalist position allows the SBC leadership to deny recognition to women serving in church leadership positions, condemn "sinful" homosexual relationships, and order a married woman to obey the commands of selected Bible verses and "submit herself graciously to the servant leadership of her husband" (Baptist Faith and Message, 2000).

The tremendous public protest that resulted from the SBC's dramatic political and theological turn to the right is reflected in 3 of the Web sites in this study. The sites are similar in several ways. Each is strongly focused on delivering information about the SBC's fundamentalist social and political viewpoints. Each makes a strong statement of protest. Each uses logic and emotion to balance the arguments being made, and each site encourages interaction with users in a variety of different ways. None of the sites encourages followers to stop identifying themselves as Baptists, however. Instead, the sites encourage followers to be Baptists who think and act independently of the SBC.

Two of the sites are particularly similar in structure and intent. The Mainstream Baptist Network and Cooperative Baptist Fellowship (CBF) sites are both large, interactive, highly developed sites sponsored by organizations that have established nationwide support. Both sites lay out their host organization's more moderate approach to social, political, and religious issues and establish "rightness with Truth" as a primary reward for the apostate actions taken. Both sites solicit donations and encourage followers to build an ongoing dialogue to oppose what is often referred to as the "fundamentalist takeover of the SBC."

The Rainbow Baptist site is much more subject focused than the others. Like the others, it protests the overall philosophical and political direction taken by the SBC-but its primary mission is that of "providing support, information and advocacy for GLBT Baptists, their family and friends." In addition to being more focused in this area, the Rainbow site seems more "grass-roots" oriented and appears to address a more youthful audience. Compared to the Mainstream and CBF sites, Rainbow is far less visually complex and operationally sophisticated.

Two of the apostate Web sites chosen for evaluation oppose the Watchtower Bible and Tract Society of Pennsylvania-better known as the Jehovah's Witnesses organization. The religious group has been termed "a controversial and widely misunderstood brand of millennialism" (Peters, 2000, p. 1). Witnesses live a conservative and somewhat sheltered lifestyle based on strict adherence to Bible teachings. 
Throughout the 1940s and 1950s, Witnesses' refusal to salute the flag or serve in the armed forces resulted in widespread brutality carried out against followers. Peters discussed in great detail the "physical violence, jailings, expulsion, and workplace discrimination" (Peters, 2000, p. 16) that Witnesses faced in communities across the country. Even today, Jehovah's Witnesses are subject to scorn for aggressive proselytization, public preaching, and core beliefs that are seen by many as outside the mainstream of Christianity.

The 2 Web sites protesting Jehovah's Witnesses are virtually identical in their structure and content. Beyond Jehovah's Witnesses and The Truth About Jehovah's Witnesses have a distinct "home made" appearance and are the only sites among those studied that appear to represent individuals and not organizational entities. Both sites are housed within domains that provide free homepage service. Even though both sites are structured around primarily logical arguments for leaving the religion, both sites claim they are not trying to dissuade people from following the Jehovah's Witnesses doctrine if they so choose. At the same time, however, both strongly protest Witnesses' theology that allegedly involves "mystical manipulation," "mind control," deceit, various illegal acts, and improper beliefs about medical care that result in unnecessary pain and suffering.

Of the 2 sites, Beyond Jehovah's Witnesses (which is currently not available online) was more complex - with more informational content and operational links. Aside from that, the differences between the 2 are mostly cosmetic.

Among the Web sites studied, only 1-Affirmation—addresses issues pertinent to members of the Church of Jesus Christ of Latter-day Saints (LDS). Affirmation represents "a fellowship of gays, lesbians, bisexuals, their family and friends who share the common bond of the Mormon experience." The site states that the group's purpose "is to provide a supportive environment for relieving the needless fear, guilt, self-oppression and isolation that LDS gays and lesbians can experience in an era where willful ignorance about human sexuality is too often a reality." In that sense, the Affirmation site is thematically similar to the Emergence and Rainbow sites. As with the others, it does not try to persuade dissidents to leave the church, but instead states its goal is that of having GLBT believers become "full and equal members of society and church."

The final site evaluated is one of only two sites that identifies its followers as former members of a church. From its opening page, Reaching Catholics for Christ identifies its followers as "ex-Catholics," leaving no doubt that the organization cannot find common ground — or encourage its followers to seek common ground — with the Holy See. Reaching Catholics for Christ makes itself very clear that its audience is the "millions of born-again ex-Catholics" who are convinced of "the unbiblical nature of Roman Catholic salvation." As with the other Web site that identifies its followers as "ex-" church members-Christian Way-Reaching Catholics for Christ is filled to overflowing with the rhetoric of protestant Christian evangelism. Given the overall strength of the site's "born again" message, the iden- 
tification of specific grievances with the Roman Catholic Church seems somewhat superfluous in context with the overall evangelistic intent.

\section{DISCUSSION}

In the class discussion preceding this research, students were presented with the idea of apostasy being a rejection of a particular religious concept, followed - typically - by a follower's personal rejection of a religious theology and disaffiliation from the religious group promulgating the theology. The students seemed to understand the concept well and spoke of events in their own family experiences that showed they understood how apostasy develops and what results from it. Most expressed the expectation that Web site content put forward by apostate groups would strongly frame a condemnation of particular religious groups, urge followers to leave specific churches, and offer alternative opportunities for worship. These expectations were not met.

Among the 10 sites studied, only 2 framed apostasy at its highest level-disengagement from a religious group. Both sites are put forward by zealous, highly evangelical Christian organizations-Christian Way and Reaching Catholics for Christ. Both identify their followers as "former" members of the churches that are targeted by their protest and were the only sites of the 10 to do so. Both were the only sites that evaluators perceived to strongly frame worship service attendance as a primary response option.

The remaining $8 \mathrm{Web}$ sites all framed apostasy as more of an intellectual response than a physical action, in the sense that all 8 of the remaining sites urged followers to reject a particular religious group's theology or a tenet of the theology - but none strongly framed disaffiliation as a response option. Even a site with one of the most virulent protests against a religious group, Beyond Jehovah's Witnesses, states "We are not here to de-convert you. ... [i]f you are happy as a Jehovah's Witness." As a result, evaluators perceived that the majority of the apostate group Web sites may put followers in a potentially awkward and ethically inconsistent position.

When an apostate Web site asks a believer to adopt a belief that is clearly opposed by the church-but at the same time not disengage from the church-to which entity is the believer faithful? Are Mormons who follow Affirmation faithful to their church because Affirmation has not told them to do otherwise, or are they disengaged from the church because they accept Affiliation's claim that same-sex relationships "can be consistent with and supported by the Gospel of Jesus Christ?"

Are Christian Scientists who follow Endtime faithful to the Church of Christ, Scientist because Endtime has not told them to do otherwise, or are they disengaged from the church because they partake in commentary and debate on Chris- 
tian Science published on the Endtime site in clear defiance of the Christian Science Publishing Society's prohibition against such action?

It could easily be argued that apostate organizations are, in many cases, seeking only to muster the support that will allow them to change the theology or practices of the opposed religious organization. Mainstream Baptists and the Cooperative Baptist Fellowship, for example, are seeking to turn back the fundamentalist policies of the SBC. Making this change will require the loyalty of apostates who are faithful to their SBC-affiliated church but aligned with an apostate organization that opposes $\mathrm{SBC}$ policies. Over the long term, this may be a reasonable strategy. But in the immediate term, it is ethically challenging for an apostate organization to ask a follower to remain true to his or her church while adhering to the apostate group's contrary theological viewpoint.

Another challenge facing apostate groups is that of attendance at worship services. Clearly, attendance at services is an important means for strengthening religious experience (Sass, 2000). Whereas most of the Web sites evaluated in this article asked visitors to read/study scripture and related information, engage in a dialogue/discussion about issues, or request further information, only 2 of the 10 sites encouraged followers to regularly attend services. Because attendance at worship services helps build a sense of community that is critical to retention of the faithful (Caplovitz, 1977), it is curious that the framing of attendance as a response option is not given a higher priority within apostate Web sites.

Only 3 of the sites explicitly asked visitors to consider joining the apostate group or to encourage others to join. This, too, seems odd. The World Wide Web is not a medium known for subtlety. It should not be left to site visitors to have to infer this response option when such an option is so important to the overall future of the apostate organization.

All of these findings, of course, are not "absolutes"- they reflect only the perceptions of those who viewed and evaluated the sites. Site creators would no doubt disagree with many of the evaluators' perceptions and the findings that resulted. Still, as the old saying goes, "perception equals reality." Regardless of the intent of the site creators, what was seen by the evaluators represents how the sites are considered - and how their content would be acted on by those contemplating a change in their religious beliefs.

\section{CONCLUSION}

This article does not represent a comprehensive content analysis of apostate Web sites. It does not represent an examination of the totality of apostate sites available for viewing on the World Wide Web. What it does represent is an initial effort to make observations about how some apostate organizations frame important issues through their Web sites and how viewer perceptions might be impacted as a result. The specific area of concern of this research is how well apostate groups are making 
use of the new medium of the World Wide Web for information dissemination, evangelization, and proselytization.

This article supports a generalization that some apostate organizations are not making the most effective use of the medium. Apostasy is a life-changing, emotional experience. The full impact of apostasy is not discussed in all its dimensions by the Web sites evaluated in this study. Those followers who would become apostates are not being shepherded through the process - from disagreement with an opposed religion's theology to disaffiliation with that group and alignment with the "new" one.

Apostate groups that identify themselves as such but do not ask followers to disaffiliate with the opposed religious group need to do much more to explain the complex strategic issues involved. It would also seem appropriate for apostate organizations to urge followers to attend services so they can establish and strengthen the interpersonal ties that are so important to retaining followers in a religious group. A more clear and decisive request for followers to formally join the organization also would be appropriate.

It has been suggested that people tend to evaluate churches in "rational, utilitarian terms" (Hadaway \& Roof, 1988, p. 35). As a result, a religious organization that does not define itself in rational, utilitarian ways may quickly be perceived as irrelevant by adherents and potential followers. Making effective use of the World Wide Web is clearly a rational, utilitarian means of communicating with these people. All the apostate groups addressed in this article are making progress in reaching out via the Web. But more can be done.

All the dynamics of the relationship between an apostate group, its adherents, potential new followers, and the opposed religious organization have not been established or investigated. Broader theoretical frameworks are needed. Much of the scholarly literature in this area is more than 10 years old. Perhaps the increasingly important role of the Internet in our society will stimulate greater interest among scholars to do research in this topic area (see Stout, 2002). We could then develop more specific and wide-ranging hypotheses about the use of the World Wide Web by apostate groups and the impact on those who would align with them.

In their examination fo the processes involved in religious disaffiliation, Hadaway and Roof said that one of the most pressing needs illustrated by the research was that of creating a "typology of apostates" (1988, p. 46) so that scholars might understand more about these people and their motives. Perhaps as research in this area is expanded in the years to come, there will also be an opportunity for us to develop a typology of apostate Web sites - something that would help us better understand how the medium is applied to address very specific human needs.

\section{REFERENCES}

Andsager, J., \& Smiley, L. (1997, July 30-August 2). Evaluating the public information function: How media agents framed the silicon breast implant controversy. Paper presented to the annual meeting of the Association for Education in Journalism and Mass Communication, Baltimore. 
Appelrouth, S. A. (1999). Shifting frames and rhetorics: A case study of the Christian Coalition of New York. Social Science Joumal, 36, 329-341.

Barr, R. (1988, February 23). Religious scandal extends "credibility crisis." Fort Lauderdale Sun-Sentinel, p. $3 \mathrm{~A}$.

Barron, A. (1993, July 4). Church flocks thinning family, cultural changes cited. Greensboro News-Record, p. Al.

Beals, A. (2002). Christian Science in the 21 st century. The Bookmark. Retrieved January 4, 2003, from http://store.yahoo.com/thebookmark/21stcentury.html

Bensimon, E. M. (1987, November 21-24). The meaning of good presidential leadership: A frame analysis. Paper presented at the annual meeting of the Association for the Study of Higher Education, Baltimore. (ERIC Document ED 292416 )

Brewer, P. R. (2002). Framing, value words, and citizens' explanations of their issue opinions. Political Communication, 19, 303-316.

Bromley, D. G. (1988). Religious disaffiliation: A neglected social process. In D. G. Bromley (Ed.), Falling from the faith: Causes and consequences of religious apostasy (pp. 9-25). Newbury Park, CA: Sage.

Caplovitz, D. (1977). The religious drop-outs. Beverly Hills, CA: Sage.

Christians, C. G. (2002). Religious perspectives on communication technology. Joumal of Media and Religion, 1, 37-47.

Collins, D. A. (2002, August 11). The church's power play. The Washington Post, p. B06. CommerceNet WorldWide Intemet Population. (2002). Retrieved November 26, 2002, from www.commerce.net/research/statistics

Curbirth, C. W., et al. (1983, May 26-30). The ethics of media framing of issues of the 1980 presidential campaign. Paper presented at the annual meeting of the International Communication Association, Dallas, TX. (ERIC Document ED 233 412)

Dehler, G. E., \& Welsh, M. A. (1994). Spirituality and organizational transformation: Implications for the new management paradigm. Joumal of Managerial Psychology, 9(6), 17-26.

Devitt, ]. (2002). Framing gender on the campaign trail: Female gubernatorial candidates and the press. Joumalism \& Mass Communication Quarterly, 79, 445-463.

Entman, R. M. (1983). Framing: Toward clarification of a fractured paradigm. Joumal of Communication, $43(1), 51-58$.

Falwell apologizes to gays, feminists, lesbians (2001, September 14). Cable News Network. Retrieved September 15, 2001 from http://www.cnn.com/2001/US/09/14/Falwell.apology/

Fan, D. P. Wyatt, R. O., \& Keltner. K. (2001). The suicidal messenger: How press reporting affects public confidence in the press, the military, and organized religion. Communication Research, 28 , $826-852$

Fraser, C. (1999). God's perfect child: Living and dying in the Christian Science Church. New York: Metropolitan Books.

Gamson, J. (2001). Jessica Hahn, media whore: Sex scandals and female publicity. Critical Studies in Media Communication, 18, 157-173.

Hadaway, C. K., \& Roof, W. C. (1988). Apostasy in American churches: Evidence from national survey data. In D. G. Bromley (Ed.), Falling from the faith: Causes and consequences of religious apostasy (pp. 29-46). Newbury Park, CA: Sage.

Hung, K. (2001). Framing meaning perceptions with music: The case of teaser ads. Joumal of Advertising, 30(3), 39-49.

Jah-Nambiar, S. (2002, August 7-10). Reframing frame analysis: Gaps and opportunities in existing research. Paper presented to the annual convention of the Association for Education in Journalism and Mass Communication, Miami Beach, FL.

Kamhawi, R, \& Weaver, D. (2003). Mass communication research trends from 1980 to 1999. Joumalism \& Mass Communication Quarterly, 80, 7-27.

Knight, M. G. (1999). Getting past the impasse: Framing as a tool for public relations. Public Relations Review, 25(3), 381-398. 
Lindlof, T. R., \& Taylor, B. C. (2002). Qhalitative commenication research methods. Thousand Oaks, CA: Sage.

Lobdell, W. (2001, December 1). Losing faith and lots more. Los Angeles Trmes, p. A1.

Lord, L. J. (1987, April 6). An unholy war in the TV pulpits. U.S. News \& World Report, pp. 58-65.

Moody-Hall, M. (2002, August 7-10). British E. U.S. newspaper framing of arabs in coverage of the Middle-Eastem conflict. Paper presented to the annual convention of the Association for Education in Journalism and Mass Communication, Miami Beach, FL.

Neck, C. P., \& Millman, J. F. (1994). Thought self-leadership: Finding spiritual fulfillment in organizational life. Joumal of Managerial Psychology, 9(6), 9-16.

Papacharissi, Z. (2002). The presentation of self in virtual life: Characteristics of personal home pages. Joumalism \& Mass Communication Quarterly, 79, 643-660.

Perloff, R. (1976). Journalism research: A twenty-year perspective. Joumalism Quarterly, 53, 123-126.

Peters, S. E. (2000). Judging Jehovah's Witnesses: Religious persecution and the dawn of the rights revolution. Lawrence: University Press of Kansas.

Potter, W. J., Cooper, R., \& Dupagne, M. (1993). The three paradigms of mass media research in mainstream communication journals. Commutnication Theory, 3(4), 317-335.

Prescott, B. (2000). The 2000 Baptist Faith \& Message: An unconscionable confession. Norman, OK: Mainstream Baptist Network.

Ragan, S. (1979, November 10-13). A frame analysis of New Yorker cartoons. Paper presented at the annual meeting of the Speech Communication Association, San Antonio, TX. (ERIC Document ED $178991)$

Riffe, D., \& Freitag, A. (1997). A content analysis of content analyses: Twenty-five years of Journalism Quarterly. Joumalism \& Mass Communication Quarterly, 74, 873-882.

Sass, J. S. (2000). Characterizing organizational spirituality: An organizational communication culture approach. Communication Studies, 51, 195-217.

Scherer, M. (2002, March/April). In review: Framing the flag, Columbia Joumalism Review, p. 10.

Scheufele, D. (1999). Framing as a theory of media effects. Joumal of Communications, 49(1), 103-122.

Schneiders, S. M. (1989). Spirituality in the academy. Theological Studies, 50, 676-697.

Shah, D. V., Watts, M. D., Domke, D., \& Fan, D. F. (2002). News framing and cueing of issue regimes: Explaining Clinton's public approval in spite of scandal. Public Opinion Quarterty, 66, 339-370.

Shermer, M. (2000). How we believe: The search for God in America. New York: Freeman.

Simons, H. W., Morreale, J., \& Gronbeck, B. (2001). Persuasion in society. Thousand Oaks, CA: Sage.

Southern Baptist Convention. (2000). Baptist Faith and Message. Retrieved January 3, 2003, from www.sbc.net/bfm/default.asp

Stout, D. A. (2002). Religious media literacy: Toward a research agenda. Joumal of Media and Religion, 1 , $49-60$.

"Swaggart accused of plagiarism." (2001, August 30). The Chattanooga Times, p. A2.

Swanson, D. J. (2001, April 18). Standing porter at the door of thought: The social order of Christian Science. Paper presented at the annual conference of the Western Social Science Association, Reno, NV.

Swanson, D. J. (in press). Homeland attack and homepage response: A preliminary review of affected business entities' online corroboration/explanation of September 11 economic impact. The Social Science Joumal.

Tankard, J. W. (1997, July 30-August 2). PR goes to war: The effects of problic relations campaigns on media framing of the Kuwaiti and Bosniam crises. Paper presented to the annual meeting of the Association for Education in Journalism and Mass Communication, Baltimore.

Tucker, L. R. (1998). The framing of Calvin Klein: A frame analysis of media discourse about the August 1995 Calvin Klein jeans advertising campaign. Critical Studies in Mass Communication, 15, 141-157.

Twain, M. (1907). Christian Science. New York: Harper \& Brothers.

Weaver, D. (1993). Communication research in the 1990s: New directions and new agendas. In P. Gaunt (Ed.), Beyond agendas: New directions in communication research (pp. 199-220). Westport, CT Greenwood. 
Witham, L. (1998, April 17-19). Manupulating the media against small religions. Speech delivered at the International Coalition for Religious Freedom Conference, Washington, DC. Retrieved September 20, 2002, from www.religiousfreedom.com/Conference/DC/witham.htm

Wright, S. A. (1988). Leaving new religious movements: Issues, theory, and research. In D. G. Bromley (Ed.), Falling from the faith: Causes and consequences of religious apostasy (pp. 143-204). Newbury Park. CA: Sage.

Zakon, R. H. (2002). Hobbes' Intemet timeline v.5.6. Retrieved November 26, 2002, from www.zakon.org 